\title{
PEMODELAN DAN SIMULASI JARINGAN BACKBONE METRO ETHERNET KOTA SEMARANG TAHUN 2028 MENGGUNAKAN SIMULATOR RIVERBED MODELER 17.5
}

\author{
Danur Ilham Khoiruman *), Sukiswo dan Ajub Ajulian Zahra \\ Departemen Teknik Elektro, Universitas Diponegoro \\ Jl. Prof. Sudharto, SH, Kampus UNDIP Tembalang, Semarang 50275, Indonesia \\ ${ }^{*}$ E-mail: danurilham@gmail.com
}

\begin{abstract}
Abstrak
Metro Ethernet merupakan salah satu teknologi untuk memberikan solusi terintegrasi untuk layanan suara, data dan video dalam cakupan yang luas (perkotaan). Teknologi ini memiliki kecepatan transmisi data sebesar 10 Mbps - 100 Gbps. Suatu jaringan harus memiliki kualitas layanan dan kapasitas yang memadai baik dari segi kapasitas link, router dan performansi QoS (Quality of Service). Pada penelitian ini, dirancang jaringan metro ethernet dengan kapasitas sesuai kebutuhan masyarakat kota Semarang tahun 2028 dengan kualias layanan yang sesuai dengan standar PT. Telkom dan ITU-T. Pemodelan dan pembuatan simulasi rancangan jaringan menggunakan perangkat lunak Riverbed Modeler 17.5. Perbandingan protocol routing RIP dan OSPF dengan parameter waktu konvergensi dilakukan sebelum analisis QoS, dengan tujuan mendapatkan rekomendasi protocol routing yang terbaik. Analisis parameter QoS yang diukur meliputi round trip delay (RTD), jitter, packet loss, utilisasi dan volume trafik. Hasil perbandingan protocol routing menunjukkan bahwa protocol routing OSPF memiliki waktu konvergensi lebih cepat 2 kali lipat dari protokol RIP. Hasil analisis QoS menyatakan bahwa QoS semua link telah sesuai dengan standar yang ada, nilai terbesar untuk RTD adalah 1,265 ms, untuk jitter adalah $0,7331 \mathrm{~ms}$, untuk packet loss ratio adalah $0,00019214 \%$, untuk utilisasi tertinggi yaitu 58,4\%, dan volume trafik terbesar adalah 91.636 Mbps.
\end{abstract}

Kata Kunci: Metro, ethernet, performansi QoS, protocol routing, RTD, jitter, utilisasi, konvergensi

\begin{abstract}
Metro Ethernet is one of the technologies to provide integrated solutions for voice, data and video services in a wide range (urban). This technology has data transmission speeds of 10 Mbps - 100 Gbps. A network must have adequate service quality and capacity both in terms of link capacity, routers and QoS (Quality of Service) performance. In this study, a metro ethernet network was designed with the capacity according to the needs of the people of the city of Semarang in 2028 with service quality in accordance with the standards of PT. Telkom and ITU-T. Modeling and making network design simulations using Riverbed Modeler 17.5 software. Comparison of RIP and OSPF routing protocols with convergence time parameters is done before QoS analysis, with the aim of getting the best routing protocol recommendations. Analysis of QoS parameters measured includes round trip delay (RTD), jitter, packet loss, utilization and traffic volume. The results of the comparison of the routing protocol indicate that the OSPF routing protocol has a convergence time that is twice as fast as the RIP protocol. The results of QoS analysis state that QoS all links are in accordance with existing standards, the largest value for RTD is $1,265 \mathrm{~ms}$, for jitter is $0.7331 \mathrm{~ms}$, for packet loss ratio is $0.00019214 \%$, for the highest utilization is $58.4 \%$, and the largest traffic volume is 91,636 Mbps.
\end{abstract}

Keywords: Metro, Ethernet, QoS performance, routing protocol, RTD, jitter, utilization, convergence

\section{Pendahuluan}

Penetrasi internet di seluruh dunia memberikan pengaruh besar dalam kehidupan umat manusia saat ini. Perkembangan teknologi informasi dan telekomunikasi dan perbaikan infrastruktur teknologi menjadi sebuah kebutuhan. Metro ethernet merupakan teknologi ethernet yang dapat menjangkau Wide Area Network (WAN) di kota besar atau metropolitan dan merupakan sistem jaringan yang cukup memadai untuk melayani kebutuhan telekomunikasi masa kini. Metro ethernet menawarkan teknologi jaringan transport yang dapat menyalurkan paket dengan kecepatan transmisi data sebesar 10 Mbps - 100 Gbps. Kota Semarang merupakan ibukota provinsi sehingga membutuhkan perencanaan jaringan yang handal untuk membangun infrastruktur jaringan yang dapat melayani pelanggan dengan kualitas pelayanan yang baik. 
Penelitian ini berfokus pada pemodelan dan pembuatan simulasi jaringan Metro Ethernet di Kota Semarang untuk kebutuhan 10 tahun mendatang dengan simulasi Riverbed Modeler 17.5 Academic Version berdasarkan hasil forecasting trafik, serta dimensioning jaringan dari penelitian saudari Sekar Nirmakumala [1]. Penentuan protocol routing juga penting untuk jaringan berskala metro, oleh karena itu pada skenario awal simulasi dibuat perbandingan protokol routing RIP dan OSPF dengan parameter pembanding waktu kovergensi. Perbandingan dilakukan dengan 3 skema pemutusan link berbeda, hasil perbandingan kemudian dijadikan protokol routing untuk pengujian kualtias layanan atau Quiality of Service. Statistik hasil pengukuran QoS yaitu Round Trip Delay (RTD), Jitter, Packet loss ratio, dan Utilisasi dibandingkan dengan standar PT. Telkom Indonesia dan ITU-T.

Pada penelitian sebelumnya, Satya Yoga [2] melakukan studi mengenai analisis QoS link metro ethernet di kota Semarang tetapi belum melakukan perancangan dan analisis total semua link. Fitri Yustina[3] melakukan studi mengenai perancangan jaringan Metro Ethernet yang sudah diterapkan dengan menganalisis performansi QoS seperti delay, jitter, packet loss, dan throughput tetapi belum melakukan pendimensian jaringan terhadap peramalan pertumbuhan bandwidth dan utilisasi link. Nuruhli Shalihah[4] menganalisis beberapa tahapan implementasi jaringan Metro Ethernet tetapi untuk layanan Mobile Broadband serta melakukan evaluasi kualitas layanan dengan parameter yang berbeda. Selain itu, referensi untuk penelitian analisis protokol dengan simulator OPNET mengacu pada penelitian milik Justin Deng dkk [5] dan Kiki Andriani dkk [6]. Kedua penelitian tersebut memiliki persamaan yaitu sama-sama membandingkan protokol routing dengan menggunakan simulator OPNET modeler 14.5. Parameter pengujian pada kedua penelitian ini memiliki persamaan yaitu parameter waktu konvergensi.

\section{Metode}

\subsection{Pemodelan Jaringan}

Pemodelan jaringan metro ethernet pada simulasi ini menggunakan topologi ring sesuai dengan hasil perancangan pada penelitian sebelumnya. Terdapat 3 ring dengan satu konsentrator sebagai node pusat yang menghubungkan 3 ring tersebut, setiap ring beranggotakan 3-5 grup node. Perancangan topologi pada skenario simulasi juga menggunakan penamaan dan pemetaan antar node yang dibuat semirip mungkin sesuai kondisi jaringan seperti Gambar 2 dan 3. serta penyesuaian IP address (interface, subnet mask dan router ID) baik pada node server maupun router switch. Sementara untuk keseluruhan perancangan simulasi, dibuat berdasarkan diagram alir dengan ditampilkan dalam bentuk tahapantahapan yang sistematis. Diagram alir perancangan simulasi secara keseluruhan dapat dilihat pada Gambar 1.
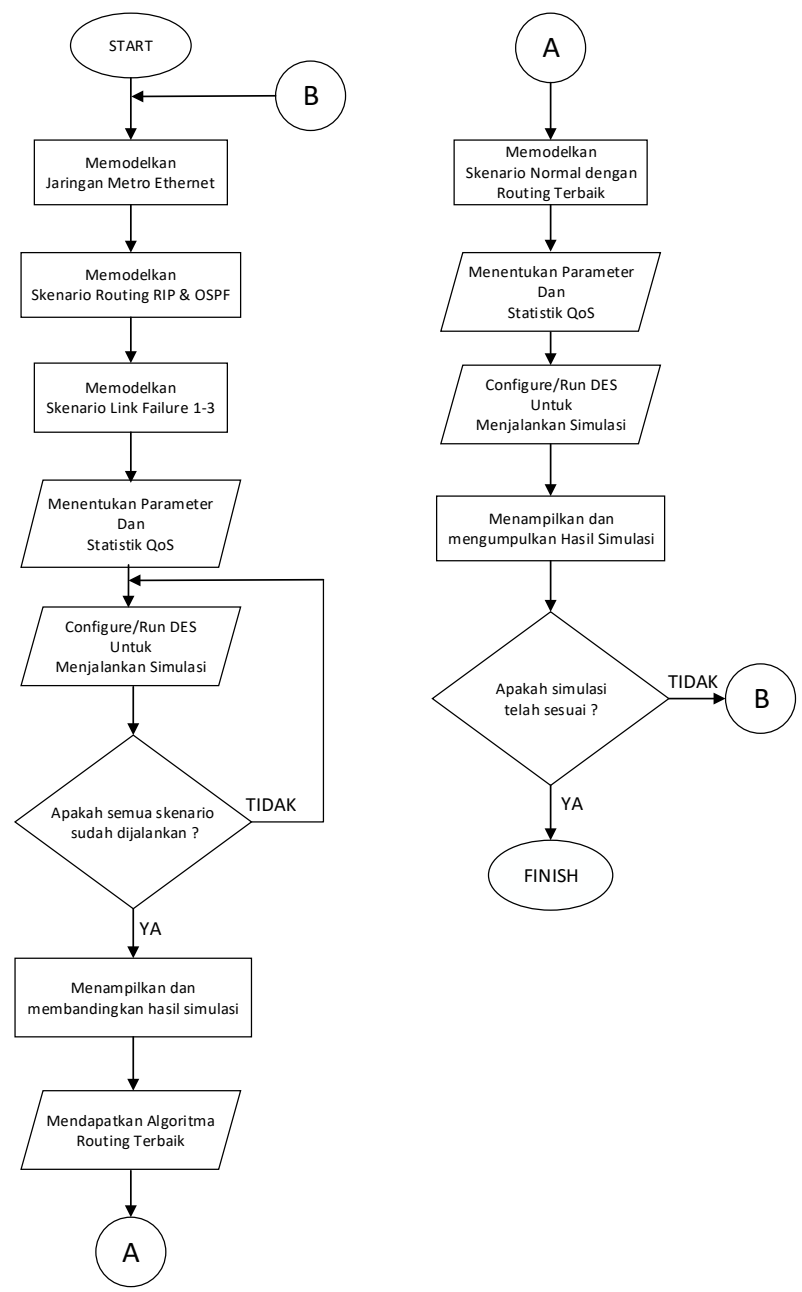

Gambar 1. Diagram Alir Simulasi

Tabel 1. Nama dan Koordinat Node

\begin{tabular}{ccccc}
\hline No & Nama Node & Simbol Node & Longitude & Latitude \\
\hline 1 & Candisari & ME_CDI & 110.4194 & -7.0195 \\
2 & Johar & ME_JHR & 110.424830 & -6.970389 \\
3 & Simpang Lima & ME_SPL & 110.422126 & -6.991442 \\
4 & Mijen & ME_MJN & 110.315782 & -7.054561 \\
5 & Mangkang & ME_MKG & 110.310282 & -6.972696 \\
6 & Tugu & ME_TUG & 110.376654 & -6.987408 \\
7 & Gombel & ME_GBL & 110.426718 & -7.045152 \\
8 & Ungaran & ME_UNR & 110.408861 & -7.149660 \\
9 & Banyumanik & ME_BMK & 110.412369 & -7.063919 \\
10 & Majapahit & ME_MPH & 110.460029 & -7.007903 \\
11 & Genuk & ME_GNK & 110.461154 & -6.956602 \\
\hline
\end{tabular}

Tabel 2. Konfigurasi Node Router

\begin{tabular}{lll}
\hline No. & Atribut & Settingan \\
\hline 1 & Module Name & Huawei Router \\
2 & Port & 108 \\
3 & OS Type & VRP \\
4 & OS Version & Unknown \\
5 & DRAM (KBytes) & $8 \times 1.000 .000$ KBytes \\
6 & NVRAM (KBytes) & $2 \times 512.000$ KBytes \\
7 & Flash RAM (KBytes) & $2 \times 512.000$ KBytes \\
\hline
\end{tabular}




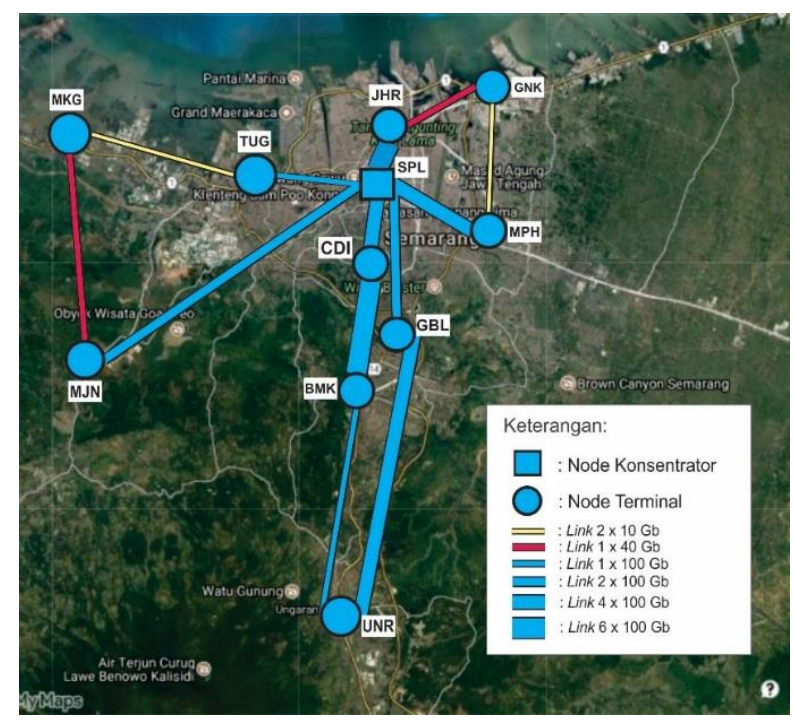

Gambar 2. Topologi hasil perencanaan Sekar [1]

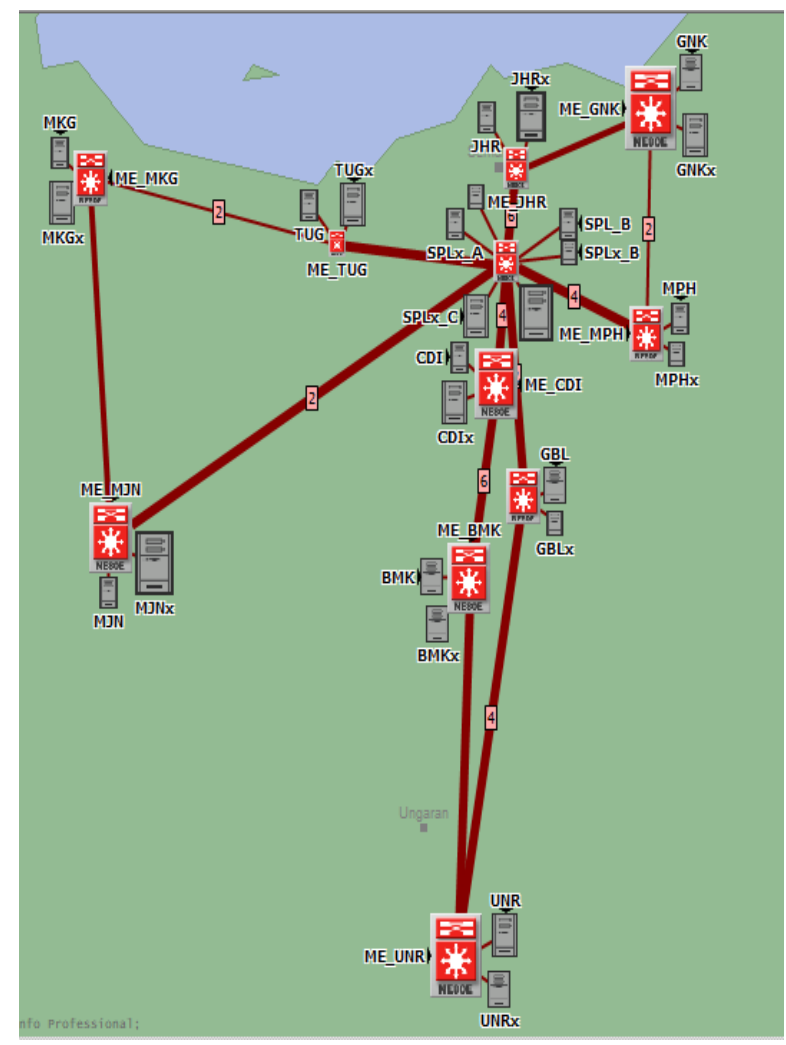

Gambar 3. Layout topologi pada simulasi

\section{Tabel 3. Konfigurasi Media Transmisi [7]}

\begin{tabular}{lll}
\hline No & Atribut & Pengaturan \\
\hline 1 & Model & $10 / 40 / 100 \mathrm{Gbps}$ Ethernet \\
2 & Propagation Speed & $200.000 .000 \mathrm{~m} / \mathrm{s}$ (speed of light in glass) \\
3 & Condition & Enabled \\
4 & Cost & 1.0 \\
5 & Delay (propagation & Menyesuaikan Jarak transmisi \\
6 & Packet Format & Ethernet, Ethernet_v2 \\
7 & Data Rate & $10 / 40 / 100 \mathrm{Gbps}$ \\
\hline
\end{tabular}

\subsection{Perbandingan Routing}

Pada penelitian ini dilakukan perbandingan protocol routing OSPF dan RIP dengan parameter pembanding adalah waktu konvergensi. Konfigurasi link failurerecovery dilakukan untuk memunculkan nilai konvergensi. Ada 3 skema waktu link failure-recovery yang dibuat. Konvergensi waktu sendiri adalah waktu saat semua router berbagi informasi, menghitung jalur terbaik, memperbaharui Routing tabel mereka. Perbandingan routing berfungsi untuk mendapatkan protocol routing terbaik dari sisi waktu konvergensi waktu[8],[9],[10].

\subsection{Pengukuran QoS}

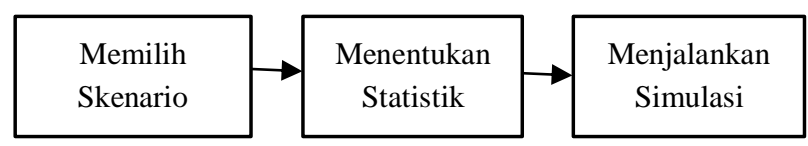

\section{Gambar 4. Diagram Alir Pengukuran QoS}

Pada pengukuran QoS untuk performansi link, langkahlangkah yang dilakukan adalah memilih skenario mana yang akan diukur (kondisi awal/forecasting) kemudian memilih statistik yang berkaitan dengan tiga parameter yang akan diukur yaitu RTD, jitter dan packet loss. Setelah itu, simulasi dijalankan hingga selesai untuk memperoleh hasil pengukuran. Standarisasi dari ketiga parameter berdasarkan PT. Telkom[11] dan ITU-T[12] ditampilkan pada Tabel 4.

Tabel 4. Standarisasi performansi link pada jaringan

\begin{tabular}{lll}
\hline Parameter & Std PT. Telkom & Std ITU-T \\
\hline Round trip delay (RTD) & $12 \mathrm{msec}$ & $<5 \mathrm{msec}$ \\
Jitter & $10 \mathrm{msec}$ & $<1 \mathrm{msec}$ \\
Packet Loss & $0,20 \%$ & $<0.001 \%$ \\
Utilisasi & Max $80 \%$ & - \\
\hline
\end{tabular}

\subsubsection{Round trip delay (RTD)}

Delay (disebut juga end-to-end delay) adalah waktu tunda suatu paket yang diakibatkan oleh proses transmisi dari satu titik ke titik lain yang menjadi tujuannya. Delay dalam suatu jaringan juga merupakan parameter yang dapat dijadikan acuan dalam menilai kualitas dan kehandalan link. Semakin tinggi nilai delay maka terdapat kemungkinan bahwa kualitas dari suatu link kurang baik. Sementara itu, round trip delay (RTD) dalam transmisi paket data merupakan penjumlahan dari dua nilai delay[13].

Namun dalam penelitian ini, dua delay yang dijumlahkan untuk perhitungan RTD tersebut berbeda. Delay yang dijumlahkan adalah delay yang diperoleh dari paket data dengan delay dari ACK (acknowledgement) yang dibangkitkan oleh TCP. Untuk delay yang diperoleh dari paket data, meliputi delay transmisi, delay propagasi dan 
delay proses dimana delay proses sendiri merupakan penjumlahan dari delay antrean dan delay layanan yang ada dalam node. Delay dari ACK pada dasarnya sama dengan delay dari paket data, hanya saja nilai delay transmisinya berbeda karena ukuran paketnya berbeda[14].

$$
R T D=\left(\tau_{T}+\tau_{\text {prop }}+\tau_{\text {proc }}\right)+\left(\tau_{\text {ack }}+\tau_{\text {prop }}+\tau_{\text {proc }}\right)
$$

Keterangan :

$$
\begin{array}{ll}
\tau_{T} & =\text { delay transmisi }(\mathrm{s} \text { atau } \mathrm{ms}) \\
\tau_{\text {prop }} & =\text { delay propagasi }(\mathrm{s} \text { atau } \mathrm{ms}) \\
\tau_{\text {ack }} & =\text { delay transmisi ACK }(\mathrm{s} \text { atau } \mathrm{ms}) \\
T_{\text {ack }} & =\text { delay total ACK }(\mathrm{s} \text { atau } \mathrm{ms}) \\
\mathrm{RTD} & =\text { round trip delay }(\mathrm{s} \text { atau } \mathrm{ms})
\end{array}
$$

\subsubsection{Jitter}

Jitter dapat didefinisikan sebagai total variasi delay antara blok-blok informasi yang berurutan. Besarnya nilai jitter akan sangat dipengaruhi oleh variasi beban trafik yang ada dalam jaringan hingga berpeluang menimbulkan tumbukan antar paket (collision). Semakin besar beban trafik di dalam jaringan akan menyebabkan semakin besar pula peluang terjadinya collision sehingga nilai jitter-nya juga akan semakin besar. Besarnya nilai jitter menandakan performansi link pada jaringan tersebut buruk sehingga nilai jitter harus dijaga seminimal mungkin untuk mendapatkan performansi link yang baik dan handal [15].

$\operatorname{Jitter}(s)=\sqrt{(\text { delay yang terjadi }- \text { rerata delay })^{2}}$

\subsubsection{Packet Loss Rasio}

Packet Loss didefinisikan sebagai kegagalan transmisi paket data untuk mencapai tujuannya. Pada implementasi jaringan IP (termasuk metro ethernet), nilai packet loss ini diharapkan mempunyai nilai yang sekecil mungkin. Kegagalan paket data dalam mencapai tujuan dapat disebabkan oleh beberapa kemungkinkan, diantaranya adalah terjadinya error transmisi, TTL (Time To Live) paket data tidak tercapai, terjadinya kemacetan (congestion) dan luapan trafik (overflow), hingga kerusakan perangkat media fisik. Untuk pengukuran packet loss, dapat menggunakan persamaan (3).

Packet Loss $=\frac{\text { Packet sent-Packet received }}{\text { Packet sent }} \times 100 \%$

\subsubsection{Utilisasi}

Utilisasi sendiri merupakan kapasitas jaringan yang terpakai dan dinyatakan dalam persen. Dalam hal ini Utilisasi/okupansi jaringan cenderung dipengaruhi langsung oleh trafik yang ditransmisikan melewati jaringan $I P$ tersebut. Standar utilisasi yang diterapkan pada perancangan jaringan metro ethernet ini adalah maksimal
$80 \%$, hal ini ditetapkan untuk mengantisipasi trafik limpahan dari link lain ketika terjadi link putus atau kegagalan node. Persamaan (4) menunjukkan perhitungan utilisasi secara matematis [16][17].

Utilisasi $=\frac{\text { Rata-rata throughput traffic }}{\text { kapasitas bandwidth dari physical link }} \times 100 \%$

\section{Hasil dan Analisis}

\subsection{Perbandingan Protokol Routing}

Parameter yang digunakan untuk data statistik perbandingan dua protokol tersebut adalah network convergence duration atau waktu konvergensi. Konvergensi sendiri mendefinisikan kondisi di mana semua router pada jaringan mancapai "kesepakatan" dalam menentukan jalur terbaik dalam routing, jadi network convergence duration adalah kecepatan waktu protokol routing dalam memperbarui tabel routing karena adanya kegagalan link atau node dalam jaringan. Semakin cepat protokol tersebut dalam membuat routing baru maka protokol tersebut semakin baik. Skema link failure dibuat untuk menunjang perbandingan sehingga kinerja dari protokol routing dapat diuji.

Tabel 5. Waktu konvergensi skema link failure pertama

\begin{tabular}{cccc}
\hline No & Parameter & OSPF $(\mathrm{sec})$ & RIP $(\mathrm{sec})$ \\
\hline 1 & Rata-rata & 6,73 & 26,218 \\
2 & Max & 17,5 & 40,779 \\
3 & Min & 4,675 & 20,806 \\
\hline
\end{tabular}

Tabel 6. Waktu konvergensi skema link failure kedua

\begin{tabular}{cccc}
\hline No & Parameter & OSPF $($ sec $)$ & RIP $($ sec $)$ \\
\hline 1 & Rata-rata & 9,364 & 22,654 \\
2 & Max & 22,52 & 88,522 \\
3 & Min & 5,752 & 2,294 \\
\hline
\end{tabular}

Tabel 7. Waktu konvergensi skema link failure ketiga

\begin{tabular}{cccc}
\hline No & Parameter & OSPF $(\mathrm{sec})$ & RIP $(\mathrm{sec})$ \\
\hline 1 & Rata-rata & 2,688 & 26,534 \\
2 & Max & 3,212 & 69,664 \\
3 & Min & 1,593 & 17,951 \\
\hline
\end{tabular}

Hasil perbandingan waktu konvergensi dari ketiga skema di atas dapat disimpulkan bahwa protokol routing OSPF memiliki hasil yang lebih baik dibandingkan dengan routing OSPF. Perbandingan kinerja protokol routing OSPF dan RIP berdasarkan waku konvergensi jaringan menunjukkan bahwa dari ketiga skema link failurerecovery routing OSPF membutuhkan waktu 2,688-9,364 detik, sedangkan untuk routing RIP membutuhkan waktu $22,654-26,534$ detik.

Hal ini terjadi karena protokol OSPF menggunakan protocol link state yang mempunyai informasi keadaan link secara keseluruhan pada topologi jaringan jadi ketika 
terjadi perubahan informasi rute secara cepat router dapat menghitung tabel routing, dengan link state pencarian rute terbaik menggunakan perhitungan cost bandwidth dan protocol OSPF menggunakan konsep hierarki untuk penyebaran informasi lebih tersegmentasi dan terstruktur sehingga waktu update informasi lebih cepat. Sedangkan pada protocol RIP menggunakan protokol distance vector dengan mengandalkan informasi router tetangganya saja, jadi ketika terjadi perubahan informasi protocol RIP membutuhkan waktu yang relative lama untuk mendapatkan informasi routing secara keseluruhan topologi.

\subsection{Pengukuran QoS}

\subsubsection{Round Trip Delay (RTD)}

Tabel 8. Hasil Pengukuran RTD

\begin{tabular}{|c|c|c|c|c|}
\hline \multirow[b]{2}{*}{ No } & \multirow[b]{2}{*}{ Link } & \multirow[b]{2}{*}{$\begin{array}{c}\text { RTD } \\
\text { (msec) }\end{array}$} & \multicolumn{2}{|c|}{ Standarisasi } \\
\hline & & & $\begin{array}{c}\text { Telkom } \\
(\sqrt{ } / X)\end{array}$ & $\begin{array}{l}\text { ITU-T } \\
\text { ( } \sqrt{ } / X)\end{array}$ \\
\hline \multirow[t]{2}{*}{1} & SPL_MPH & 1,28361 & $\sqrt{ }$ & $\sqrt{ }$ \\
\hline & MPH_SPL & 1,11390 & $\sqrt{ }$ & $\sqrt{ }$ \\
\hline \multirow[t]{2}{*}{2} & MPH_GNK & 1,03851 & $\sqrt{ }$ & $\sqrt{ }$ \\
\hline & GNK_MPH & 1,12191 & $\sqrt{ }$ & $\sqrt{ }$ \\
\hline \multirow[t]{2}{*}{3} & GNK_JHR & 1,14331 & $\sqrt{ }$ & $\sqrt{ }$ \\
\hline & JHR_GNK & 1,22484 & $\sqrt{ }$ & $\sqrt{ }$ \\
\hline \multirow[t]{2}{*}{4} & JHR_SPL & 1,08132 & $\sqrt{ }$ & $\sqrt{ }$ \\
\hline & SPL_JHR & 0,98591 & $\sqrt{ }$ & $\sqrt{ }$ \\
\hline \multirow[t]{2}{*}{5} & CDI_BMK & 1,02357 & $\sqrt{ }$ & $\sqrt{ }$ \\
\hline & BMK_CDI & 1,06495 & $\sqrt{ }$ & $\sqrt{ }$ \\
\hline \multirow[t]{2}{*}{6} & BMK_UNR & 1,06547 & $\sqrt{ }$ & $\sqrt{ }$ \\
\hline & UNR_BMK & 1,06776 & $\sqrt{ }$ & $\sqrt{ }$ \\
\hline \multirow[t]{2}{*}{7} & UNR_GBL & 1,15799 & $\sqrt{ }$ & $\sqrt{ }$ \\
\hline & GBL_UNR & 1,13815 & $\sqrt{ }$ & $\sqrt{ }$ \\
\hline \multirow[t]{2}{*}{8} & GBL_SPL & 1,01063 & $\sqrt{ }$ & $\sqrt{ }$ \\
\hline & SPL_GBL & 0,99489 & $\sqrt{ }$ & $\sqrt{ }$ \\
\hline \multirow[t]{2}{*}{9} & CDI_SPL & 0,94876 & $\sqrt{ }$ & $\sqrt{ }$ \\
\hline & SPL_CDI & 1,02983 & $\sqrt{ }$ & $\sqrt{ }$ \\
\hline \multirow[t]{2}{*}{10} & SPL_MJN & 1,16322 & $\sqrt{ }$ & $\sqrt{ }$ \\
\hline & MJN_SPL & 1,16839 & $\sqrt{ }$ & $\sqrt{ }$ \\
\hline \multirow[t]{2}{*}{11} & MJN_MKG & 1,07741 & $\sqrt{ }$ & $\sqrt{ }$ \\
\hline & MKG_MJN & 1,14447 & $\sqrt{ }$ & $\sqrt{ }$ \\
\hline \multirow[t]{2}{*}{12} & MKG_TUG & 1,38280 & $\sqrt{ }$ & $\sqrt{ }$ \\
\hline & TUG_MKG & 1,19582 & $\sqrt{ }$ & $\sqrt{ }$ \\
\hline \multirow[t]{2}{*}{13} & TUG_SPL & 0,99178 & $\sqrt{ }$ & $\sqrt{ }$ \\
\hline & SPL_TUG & 1,07298 & $\sqrt{ }$ & $\sqrt{ }$ \\
\hline
\end{tabular}

Hasil dari perhitungan nilai RTD pada Tabel 8 . menunjukkan bahwa dari 26 link telah sesuai dengan standar yang ditentukan oleh Telkom dan ITU-T dengan rata-rata nilai RTD keseluruhan adalah $1,10355 \mathrm{~ms}$. RTD rata-rata tersebut jauh di bawah standar Telkom (12 ms) dan ITU-T (5 ms). Nilai RTD paling tinggi terdapat pada link MKG_TUG yaitu $1,38280 \mathrm{~ms}$, sedangkan untuk nilai RTD paling rendah atau terbaik terdapat pada link CDI_SPL adalah 0,94876 ms.
Tingginya nilai RTD dipengaruhi oleh nilai delay antrean rata-rata dalam node yang berkaitan erat dengan ruang buffer dan memori pada perangkat. Pada simulasi yang telah dilakukan, salah satu penyebab terbesar yang mempengaruhi banyaknya antrian data karena adanya indikasi perilaku TCP (duplikat ACK, retransmisi data, reset connection, dan lain-lain) yang terlalu sering terjadi. Hal tersebut menyebabkan trafik yang dibangkitkan pada forwarding rate tidak langsung ditransmisikan dan data harus ditampung terlebih dahulu di dalam ruang memori (node) ataupun ruang buffer (interface), sedangkan intensitas trafik terus meningkat mengikuti trafik-trafik baru yang dibangkitkan.

\subsubsection{Jitter}

Tabel 9. Hasil Pengukuran Jitter

\begin{tabular}{|c|c|c|c|c|}
\hline \multirow[b]{2}{*}{ No } & \multirow[b]{2}{*}{ Link } & \multirow[b]{2}{*}{$\begin{array}{c}\text { Jitter } \\
\text { (msec) }\end{array}$} & \multicolumn{2}{|c|}{ Standarisasi } \\
\hline & & & $\begin{array}{c}\text { Telkom } \\
(\sqrt{ } / X)\end{array}$ & $\begin{array}{l}\text { ITU-T } \\
(\sqrt{ } / X)\end{array}$ \\
\hline \multirow[t]{2}{*}{1} & SPL_MPH & 0,702729209 & $\sqrt{ }$ & $\sqrt{ }$ \\
\hline & MPH_SPL & 0,753835716 & $\sqrt{ }$ & $\sqrt{ }$ \\
\hline \multirow[t]{2}{*}{2} & MPH_GNK & 0,727498155 & $\sqrt{ }$ & $\sqrt{ }$ \\
\hline & GNK_MPH & 0,731142917 & $\sqrt{ }$ & $\sqrt{ }$ \\
\hline \multirow[t]{2}{*}{3} & GNK_JHR & 0,659236216 & $\sqrt{ }$ & $\sqrt{ }$ \\
\hline & JHR_GNK & 0,603441667 & $\sqrt{ }$ & $\sqrt{ }$ \\
\hline \multirow[t]{2}{*}{4} & JHR_SPL & 0,706125126 & $\sqrt{ }$ & $\sqrt{ }$ \\
\hline & SPL_JHR & 0,667602442 & $\sqrt{ }$ & $\sqrt{ }$ \\
\hline \multirow[t]{2}{*}{5} & CDI_BMK & 0,694074853 & $\sqrt{ }$ & $\sqrt{ }$ \\
\hline & BMK_CDI & 0,623598162 & $\sqrt{ }$ & $\sqrt{ }$ \\
\hline \multirow[t]{2}{*}{6} & BMK_UNR & 0,796264454 & $\sqrt{ }$ & $\sqrt{ }$ \\
\hline & UNR_BMK & 0,781045915 & $\sqrt{ }$ & $\sqrt{ }$ \\
\hline \multirow[t]{2}{*}{7} & UNR_GBL & 0,562613635 & $\sqrt{ }$ & $\sqrt{ }$ \\
\hline & GBL_UNR & 0,471741365 & $\sqrt{ }$ & $\sqrt{ }$ \\
\hline \multirow[t]{2}{*}{8} & GBL_SPL & 0,667441318 & $\sqrt{ }$ & $\sqrt{ }$ \\
\hline & SPL_GBL & 0,605844736 & $\sqrt{ }$ & $\sqrt{ }$ \\
\hline \multirow[t]{2}{*}{9} & CDI_SPL & 0,732068753 & $\sqrt{ }$ & $\sqrt{ }$ \\
\hline & SPL_CDI & 0,764099598 & $\sqrt{ }$ & $\sqrt{ }$ \\
\hline \multirow[t]{2}{*}{10} & SPL_MJN & 0,678408387 & $\sqrt{ }$ & $\sqrt{ }$ \\
\hline & MJN_SPL & 0,644255384 & $\sqrt{ }$ & $\sqrt{ }$ \\
\hline \multirow[t]{2}{*}{11} & MJN_MKG & 0,673826896 & $\sqrt{ }$ & $\sqrt{ }$ \\
\hline & MKG_MJN & 0,722146087 & $\sqrt{ }$ & $\sqrt{ }$ \\
\hline \multirow[t]{2}{*}{12} & MKG_TUG & 0,595946518 & $\sqrt{ }$ & $\sqrt{ }$ \\
\hline & TUG_MKG & 0,620711976 & $\sqrt{ }$ & $\sqrt{ }$ \\
\hline \multirow[t]{2}{*}{13} & TUG_SPL & 0,616809711 & $\sqrt{ }$ & $\sqrt{ }$ \\
\hline & SPL_TUG & 0,550607032 & $\sqrt{ }$ & $\sqrt{ }$ \\
\hline
\end{tabular}

Data hasil pengukuran jitter pada Tabel 9. menunjukkan klasifikasi bahwa semua link pada simulasi perancangan metro ethernet telah sesuai dengan standar yang ditentukan oleh Telkom (10 ms) dan ITU-T (1 ms) sesuai pada Tabel 4. Jitter rata-rata pada hasil simulasi adalah $0,66743 \mathrm{~ms}$, nilai ini masih berada dibawah standar yang ditentukan. Untuk waktu jitter tertinggi adalah 0,796264454 ms terdapat pada link BMK_UNR, sedangakan untuk nilai jitter terendah terdapat pada link GBL_UNR yaitu $0,471741365 \mathrm{~ms}$. Nilai pada parameter jitter dipengaruhi oleh variasi beban trafik dan besarnya tumbukan antar paket (congestion) yang ada dalam jaringan IP. 


\subsubsection{Packet Loss Ratio}

Tabel 10 menampilkan hasil statistik Packet Loss Ratio dari simulasi perancangan jaringan metro ethernet, dari data tersebut dapat dilihat bahwa klasifikasi untuk semua link telah sesuai dengan standar yang berlaku yaitu bernilai kurang nilai standarisasi pada Tabel 4. Link yang mempunyai tertinggi adalah GBL_SPL dan sebaliknya yaitu 0,00019214 \%. Ada pun yang memiliki Packet Loss Ratio 0 yang berarti semua paket data yang dikirim telah diterima $100 \%$ tanpa adanya data yang hilang.

Tabel 10. Hasil Pengukuran Packet Loss Ratio

\begin{tabular}{|c|c|c|c|c|}
\hline \multirow[b]{2}{*}{ No } & \multirow[b]{2}{*}{ Link } & \multirow[b]{2}{*}{ Packet Loss Ratio } & \multicolumn{2}{|c|}{ Standarisasi } \\
\hline & & & $\begin{array}{c}\text { Telkom } \\
(\sqrt{ } / X)\end{array}$ & $\begin{array}{l}\text { ITU-T } \\
(\sqrt{ } / X)\end{array}$ \\
\hline \multirow[t]{2}{*}{1} & SPL_MPH & 0,00003726 & $\sqrt{ }$ & $\sqrt{ }$ \\
\hline & MPH_SPL & 0,00003726 & $\sqrt{ }$ & $\sqrt{ }$ \\
\hline \multirow[t]{2}{*}{2} & MPH_GNK & 0 & $\sqrt{ }$ & $\sqrt{ }$ \\
\hline & GNK_MPH & 0 & $\sqrt{ }$ & $\sqrt{ }$ \\
\hline \multirow[t]{2}{*}{3} & GNK_JHR & 0,00002844 & $\sqrt{ }$ & $\sqrt{ }$ \\
\hline & JHR_GNK & 0,00002844 & $\sqrt{ }$ & $\sqrt{ }$ \\
\hline \multirow[t]{2}{*}{4} & JHR_SPL & 0,000061151 & $\sqrt{ }$ & $\sqrt{ }$ \\
\hline & SPL_JHR & 0,000061151 & $\sqrt{ }$ & $\sqrt{ }$ \\
\hline \multirow[t]{2}{*}{5} & CDI_BMK & 0,00008316751 & $\sqrt{ }$ & $\sqrt{ }$ \\
\hline & BMK_CDI & 0,00008316751 & $\sqrt{ }$ & $\sqrt{ }$ \\
\hline \multirow[t]{2}{*}{6} & BMK_UNR & 0,00007428 & $\sqrt{ }$ & $\sqrt{ }$ \\
\hline & UNR_BMK & 0,00007428 & $\sqrt{ }$ & $\sqrt{ }$ \\
\hline \multirow[t]{2}{*}{7} & UNR_GBL & 0 & $\sqrt{ }$ & $\sqrt{ }$ \\
\hline & GBL_UNR & 0 & $\sqrt{ }$ & $\sqrt{ }$ \\
\hline \multirow[t]{2}{*}{8} & GBL_SPL & 0,00019214 & $\sqrt{ }$ & $\sqrt{ }$ \\
\hline & SPL_GBL & 0,00019214 & $\sqrt{ }$ & $\sqrt{ }$ \\
\hline \multirow[t]{2}{*}{9} & CDI_SPL & 0,00003833 & $\sqrt{ }$ & $\sqrt{ }$ \\
\hline & SPL_CDI & 0,00003833 & $\sqrt{ }$ & $\sqrt{ }$ \\
\hline \multirow[t]{2}{*}{10} & SPL_MJN & 0,00004110 & $\sqrt{ }$ & $\sqrt{ }$ \\
\hline & MJN_SPL & 0,00004110 & $\sqrt{ }$ & $\sqrt{ }$ \\
\hline \multirow[t]{2}{*}{11} & MJN_MKG & 0,00006440 & $\sqrt{ }$ & $\sqrt{ }$ \\
\hline & MKG_MJN & 0,00006440 & $\sqrt{ }$ & $\sqrt{ }$ \\
\hline \multirow[t]{2}{*}{12} & MKG_TUG & 0 & $\sqrt{ }$ & $\sqrt{ }$ \\
\hline & TUG_MKG & 0 & $\sqrt{ }$ & $\sqrt{ }$ \\
\hline \multirow[t]{2}{*}{13} & TUG_SPL & 0,00005829 & $\sqrt{ }$ & $\sqrt{ }$ \\
\hline & SPL_TUG & 0,00005829 & $\sqrt{ }$ & $\sqrt{ }$ \\
\hline
\end{tabular}

Packet loss muncul karena beberapa faktor. Faktor pertama adalah terjadi kegagalan sinkronisasi ataupun noise pada saat transmisi data. Meskipun error yang dihasilkan sangatlah kecil, hal ini dikarenakan media transmisi yang digunakan adalah wired fiber optic berkecepatan cahaya sehingga sangat sedikit noise yang dihasilkan, terlebih lagi jarak transmisi yang tidak begitu jauh karena hanya dalam kota saja. Faktor selanjutnya adalah TTL (Time To Live) paket tidak tercapai karena paket terlalu lama berada di dalam jaringan dan tak kunjung sampai pada tujuan karena permasalahan routing. Faktor terakhir yang berpeluang menimbulkan packet loss adalah ketika laju kedatangan pertumbuhan trafik sama dengan atau lebih besar dari kemampuan pelayanan (laju layanan) perangkat dalam jaringan $(\lambda \geq \mu)$ sehingga dapat menyebabkan kemacetan (congestion) hingga luapan trafik (overflow).

\subsubsection{Utilisasi}

Standarisasi pada parameter QoS utilisasi hanya mengacu pada standar Telkom. Pada Tabel 11. menunjukkan bahwa pada link SPL_TUG, CDI_SPL, GBL_SPL, MPH_SPL berada pada posisi "peringatan" karena melebihi batas utilisasi 50\% namun keempat link tersebut hanya melebihi $1-8,4 \%$. Berdasarkan wawancara penulis dengan manager operator PT.Telkom bagian network operation, kelebihan $8,4 \%$ masih dianggap wajar selama belum mencapai angka $80 \%$ karena jika sudah mencapai $80 \%$ artinya wajib ditambah kapasitas link tersebut.

\section{Tabel 11. Hasil Pengukuran Utilisasi}

\begin{tabular}{llcc}
\hline No & Link & Utilisasi & Std PT. Telkom \\
\hline 1 & SPL_MPH & 30,6 & $\sqrt{ }$ \\
2 & MPH_SPL & 58,4 & $\sqrt{ }$ \\
3 & MPH_GNK & 36 & $\sqrt{ }$ \\
4 & GNK_MPH & 20,4 & $\sqrt{ }$ \\
5 & GNK_JHR & 19,7 & $\sqrt{ }$ \\
6 & JHR_GNK & 32 & $\sqrt{ }$ \\
7 & JHR_SPL & 40,6 & $\sqrt{ }$ \\
8 & SPL_JHR & 24,9 & $\sqrt{ }$ \\
9 & CDI_BMK & 40,9 & $\sqrt{ }$ \\
10 & BMK_CDI & 20,9 & $\sqrt{ }$ \\
11 & BMK_UNR & 44 & $\sqrt{ }$ \\
12 & UNR_BMK & 11,3 & $\sqrt{ }$ \\
13 & UNR_GBL & 23 & $\sqrt{ }$ \\
14 & GBL_UNR & 38,3 & $\sqrt{ }$ \\
15 & GBL_SPL & 58,1 & $\sqrt{ }$ \\
16 & SPL_GBL & 19,8 & $\sqrt{ }$ \\
17 & CDI_SPL & 56,4 & $\sqrt{ }$ \\
18 & SPL_CDI & 29,9 & $\sqrt{ }$ \\
19 & SPL_MJN & 36,2 & $\sqrt{ }$ \\
20 & MJN_SPL & 12,7 & $\sqrt{ }$ \\
21 & MJN_MKG & 36,3 & $\sqrt{ }$ \\
22 & MKG_MJN & 25,7 & $\sqrt{ }$ \\
23 & MKG_TUG & 15,2 & $\sqrt{ }$ \\
24 & TUG_MKG & 35,4 & $\sqrt{ }$ \\
25 & TUG_SPL & 19,7 & \\
26 & SPL_TUG & 50,2 & \\
\hline & & & \\
\hline
\end{tabular}

Nilai utilisasi tertinggi ada pada link MPH_SPL yaitu 58,4 $\%$, sedangkan nilai utilisasi terendah terdapat pada link UNR_BMK yaitu 11,3\%. Nilai standar $<50 \%$ ini di tentukan berdasarkan teori bahwa jika ada link putus pada ring tertentu maka link pada jaringan tersebut dapat menampung limpahan trafik dari link yang putus. Utilisasi pada suatu link tidak sama dikarenakan trafik inbound dan outbound-nya berbeda atau bahkan bisa berbanding terbalik.

\section{Kesimpulan}

Berdasarkan hasil penelitian ini, jaringan metro ethernet yang dimodelkan pada terdapat total 11 node router menggunakan Router Huawei NE80E dengan kapasitas 10 
Tbps dan link yang digunakan adalah Gigabit Ethernet fiber optic berkapasitas $10 \mathrm{Gbps}, 40 \mathrm{Gbps}$, dan $100 \mathrm{Gbps}$, serta server yang digunakan adalah ethernet server tipe Solaris Sun Ultra 2 Model 1400. Perbandingan kinerja protokol routing OSPF dan RIP berdasarkan waku konvergensi jaringan menunjukkan bahwa dari ketiga skema link failure-recovery routing OSPF membutuhkan waktu 2,688 - 9,364 detik, sedangkan untuk routing RIP membutuhkan waktu 22,654 - 26,534 detik. Hasil tersebut menunjukkan bahwa routing OSPF lebih baik dari RIP sehingga routing OSPF dipilih sebagai protokol routing yang digunakan dalam perancangan jaringan metro ethernet. Pada pengukuran QoS parameter round trip delay (RTD) menunjukkan bahwa seluruh link dalam jaringan yang dirancang telah sesuai dengan standarisasi QoS yang ditentukan yaitu sebesar $12 \mathrm{~ms}$ (Telkom) dan < $5 \mathrm{~ms}$ (ITUT). Nilai tertinggi yang terukur untuk parameter RTD terdapat pada link MKG_TUG yaitu 1,38280 ms, sedangkan untuk nilai RTD paling rendah atau terbaik terdapat pada link CDI_SPL adalah 0,94876 ms. Kemudian pada parameter jitter atau variasi delay menunjukkan bahwa semua link dalam jaringan yang dirancang telah sesuai dengan standarisasi QoS yang ditentukan yaitu sebesar $10 \mathrm{~ms}$ (Telkom) dan < $1 \mathrm{~ms}$ (ITU-T). Nilai jitter tertinggi adalah $0,796264454 \mathrm{~ms}$ terdapat pada link BMK_UNR, sedangkan untuk nilai jitter terendah terdapat pada link GBL_UNR yaitu 0,471741365 ms. Sedangkan untuk parameter packet loss menunjukkan bahwa semua link dalam jaringan yang dirancang telah sesuai dengan standarisasi QoS yang ditentukan yaitu sebesar 0,2 \% (Telkom) dan $<0,001 \%$ (ITU-T). Nilai tertinggi yang terukur untuk parameter packet loss ratio terdapat pada link GBL - SPL dengan nilai 0,00019214 \%. Pada pengukuran utilisasi menunjukkan bahwa semua link dalam jaringan yang dirancang telah sesuai dengan standarisasi QoS yang ditentukan yaitu sebesar maksimal $80 \%$ (Telkom). Nilai tertinggi yang terukur untuk parameter utilisasi terdapat pada link MPH - SPL dengan nilai 58,4\%, sedangkan nilai utilisasi terendah terdapat pada link UNR_BMK yaitu 11,3 $\%$.

\section{Referensi}

[1]. Sekar Nirmakumala, "Perencanaan Jaringan Backbone Metro Ethernet Kota Semarang Tahun 2028 Menggunakan Algoritma Dysart dan Georganas Serta Metode Hungarian dan Forecasting Kruithof's Double Factor", Laporan Tugas Akhir, Departemen Teknik Elektro, Universitas Diponegoro, Semarang, 2018.
[2]. Satya Yoga P., "Analisis Performansi Link Pada Jaringan Metro Ethernet Regional Jawa Tengah Menggunakan Simulator OPNET 14.5", Laporan Tugas Akhir, Departemen Teknik Elektro, Universitas Diponegoro, Semarang, 2017.

[3]. Fitri Yustina, "Studi Perancangan Jaringan Teknologi Metro Ethernet Untuk Jaringan Telekomunikasi Eksternal Universitas Lampung”, Universitas Lampung, 2010.

[4]. Nuruhli Shalihah, "Implementasi Jaringan Metro Ethernet PT. Telkom untuk Akses Layanan Mobile Broadband PT. Telkomsel Area Jakarta", Laporan Tugas Akhir, Program Studi Teknik Elektro, Universitas Indonesia, Depok, 2010.

[5]. Justin Deng, Siheng Wu, Kenny Sun, “Comparison of RIP, OSPF, and EIGRP Routing Protokols based on OPNET", Communication network, Simon Fraser University, Canada, 2014.

[6]. Kiki Andriani, Istikmal, Muhammad Iqbal, "Simulasi dan Analisis routing Jaringan Metro Ethernet dengan menggunakan RIPNG dan OSPF pada IPV6", Laporan Tugas Akhir, Teknik Telekomunikasi,Universitas Telkom, Bandung, 2011

[7]. EXFO Inc., "EtherSAM: The New Standard In Ethernet Service Testing,"

[8]. Kadek Chandra T. W., "Analisis Kinerja RIP (Routing Information Protocol) Untuk Optimalisasi Jalur Routing", Laporan Tugas Akhir, Jurusan Ilmu Komputer, Universitas Udayana, Bali, 2012

[9]. Handriyanto, D. F., "Kajian Penggunaan Mikrotik Router Os ${ }^{\mathrm{TM}}$ Sebagai Router Pada Jaringan Komputer", Teknik Informatika, Universitas Sriwijaya, 2009.

[10]. Graziani, R., dan Johnson, A. Routing Protocols and Concepts, CCNA Exploration Companion Guide. Texas: Cisco, 2008.

[11]. PT Telkom Indonesia, "Preventive Maintenance Metro Ethernet Huawei," NITS Academy TCU-C Bandung. 2013.

[12]. A. Kasim, Delivering Carrier Ethernet: Extending Ethernet Beyond the LAN. The McGraw-Hill Companies United States of America, 2008.

[13]. S. N. Hertiana, Rekayasa Trafik Telekomunikasi. Institut Teknologi Telkom Bandung, 2009.

[14]. Forouzan, A.. Data Communications And Networking 4th Edition. New York: McGraw-Hill, 2007.

[15]. Melvin Syafrizal, Pengantar Jaringan Komputer, Andi: Yogyakarta, 2005

[16]. PT Telkom Indonesia, Kebijakan Pengelolaan Infrastruktur Infocom Divisi Infratel KV.85/TK000/DIT-050/2009. Semarang, 2009.

[17]. Fatoni. “Analisis Kualitas Layanan Jaringan Intranet", Universitas Bina Darma, Palembang, 2011. 